\title{
Korelasi lingkar pinggang dan rasio lingkar pinggang-panggul terhadap kadar glukosa plasma menggunakan tes toleransi glukosa oral
}

Correlation between waist circumference (WC) and waist-hip ratio (WHR) with plasma glucose levels using oral glucose tolerance test method

\author{
Farida Dwi Rokhmah ${ }^{1}$, Dian Handayani ${ }^{1}$, Harun Al-Rasyid ${ }^{2}$ \\ Program Studi Ilmu Gizi Kesehatan, Fakultas Kedokteran Universitas Brawijaya Malang \\ Program Studi Pendidikan Dokter, Fakultas Kedokteran Universitas Brawijaya Malang
}

\begin{abstract}
Background: The increased circumference of waist and waist-hip ratio describe intra-abdominal fat which is associated with a number of metabolic disorders such as diabetes mellitus. Objectives: The aim of the study is analyze the correlation between circumference of waist and waist-hip ratio in plasma glucose levels using the Oral Glucose Tolerance Test (OGTT) method in adults. Methods: This study was a cross sectional study involving 75 respondents from Klojen which is located in Malang and obtained by multistage sampling random. The variables in the study include circumference of waist, waist-hip ratio, fasting plasma glucose and plasma glucose after consuming glucose liquid. Data were analyzed using coefficient contingency and Spearman correlation. Results: This study found that based on waist circumference and waist-hip ratio, most of subjects are categorized as not at risk. Furthermore, based on plasma glucose level measurement using OGTT, 96\% of subjects are normal. Conclusion: There is no correlation between plasma glucose level using OGTT and waist circumference as well as waist-hip ratio ( $p>0.05)$.
\end{abstract}

KEY WORDS: oral glucose tolerance test; plasma glucose; waist circumference; waist-hip ratio

\begin{abstract}
ABSTRAK
Latar belakang: Peningkatan lingkar pinggang dan rasio lingkar pinggang-panggul dapat menggambarkan lemak intra-abdomen yang bisa menyebabkan resiko tinggi pada sejumlah penyakit, seperti diabetes mellitus. Tujuan: Penelitian ini bertujuan untuk menganalisis hubungan lingkar pinggang dan rasio lingkar pinggang-panggul dengan kadar glukosa plasma menggunakan metode Tes Toleransi Glukosa Oral pada orang dewasa dimana responden diminta untuk bersedia diukur glukosa plasma sebelum dan setelah mengonsumsi larutan glukosa. Metode: Penelitian ini merupakan penelitian Cross sectional yang melibatkan 75 responden berumur lebih dari 18 tahun sampai 40 tahun dan tidak memiliki penyakit diabetes serta tidak sedang hamil yang berasal dari Kelurahan Klojen di Kota Malang, Jawa Timur dan diperoleh dengan Multistage Random Sampling. Variabel pada penelitian ini meliputi lingkar pinggang, rasio lingkar pinggang- panggul, kadar glukosa plasma puasa dan kadar glukosa plasma 2 jam setelah mengonsumsi larutan glukosa. Data dianalisis menggunakan Contingency Coefficient dan Spearman Correlation. Hasil: Hasil penelitian menunjukkan bahwa berdasarkan lingkar pinggang dan rasio lingkar pinggang-panggul, sebagian besar responden tergolong tidak berisiko mengalami diabetes. Begitu pula hasil pemeriksaan glukosa plasma menggunakan tes toleransi glukosa oral, sebagian besar responden (96\%) berada dalam kategori normal yang berarti bahwa sebagian responden tidak memiliki prediabetes. Simpulan: Penelitian ini tidak menemukan korelasi antara lingkar pinggang dan rasio lingkar pinggang-panggul dengan kadar glukosa plasma menggunakan tes toleransi gukosa oral $(\mathrm{p}>0,05)$.
\end{abstract}

KATA KUNCI: TTGO; kadar glukosa plasma; lingkar pinggang; rasio lingkar pinggang-panggul

\section{PENDAHULUAN}

Antropometri merupakan suatu studi yang mengukur tubuh manusia dari berbagai dimensi yaitu tulang, otot dan jaringan lemak. Contoh pengukuran antropometri diantaranya berat badan, tinggi badan, lingkar pinggang, lingkar panggul, tebal lemak (bisep, trisep, suprailiac dll), dan lingkar lengan atas (1). Perbedaan dalam prosedur pengukuran diantara beberapa

Korespondensi: Farida Dwi Rokhmah, Program Studi Ilmu Gizi Kesehatan Fakultas Kedokteran Universitas Brawijaya Malang, Jl. Veteran, Ketawanggede, Lowokwaru, Malang, Jawa Timur 65145, e-mail: faridadwirokhmah@gmail.com 
penelitian bisa menghasilkan variasi yang berbeda, contohnya dalam menentukan titik tengah untuk mengukur lingkar pinggang, serta hubungannya dengan faktor risiko, penyakit atau outcome lain (2). Korelasi suatu pengukuran antropometri dengan suatu parameter gangguan metabolik pada suatu etnis dapat memiliki nilai korelasi yang berbeda dengan etnis lain (3).

Pengukuran antropometri memiliki beberapa keuntungan yaitu mampu menyediakan informasi mengenai riwayat gizi masa lalu, yang tidak dapat diperoleh dengan bukti yang sama melalui metode pengukuran lainnya. Pengukuran ini dapat dilakukan dengan relatif cepat, mudah, dan reliable menggunakan peralatan-peralatan portable, tersedianya metode-metode yang terstandarisasi, dan digunakannya peralatan yang terkalibrasi (4).

Berdasarkan hasil Riskesdas tahun 2013 proporsi obesitas berdasarkan indeks massa tubuh (IMT) pada perempuan ( $>18$ Tahun) di Indonesia prevalensinya sebesar $32,9 \%$, sedangkan di Jawa Timur memiliki prevalensi yang lebih tinggi yaitu $34 \%$. Prevalensi obesitas pada laki-laki (>18 Tahun) di Indonesia dan Jawa Timur sama yaitu sebesar $19,7 \%$. Sedangkan prevalensi obesitas abdominal berdasarkan lingkar pinggang (LP), Indonesia memiliki prevalensi 26,6\%. Provinsi Jawa timur memiliki prevalensi $26,6 \%$ yang sama dengan prevalensi di Indonesia. Obesitas khususnya obesitas abdominal berkorelasi dengan beberapa gangguan metabolisme dan penyakit, dengan angka kesakitan dan kematian yang tinggi, antara lain resistensi insulin dan diabetes mellitus, hipertensi, hiperlipidemia, aterosklerosis, penyakit hati dan kandung empedu, bahkan beberapa jenis kanker (5).

Indikator yang digunakan untuk mengukur obesitas diantaranya adalah pengukuran lingkar pinggang, rasio lingkar pinggang-panggul (RLPP) dan IMT. IMT dihitung dengan membagi berat badan dalam kilogram dengan tinggi badan dikuadratkan dalam meter. Kelemahan pengukuran antropometri dengan IMT adalah tidak dapat menilai distribusi lemak dalam tubuh sehingga kurang sensitif untuk menentukan obesitas abdominal (6).

Pengukuran lingkar pinggang lebih sensitif dalam menilai distribusi lemak dalam tubuh terutama yang berada di dinding abdomen dan juga digunakan untuk mengidentifikasi 2 tipe dari distribusi lemak, yaitu tipe android (pada bagian atas) dan gynecoid (pada bagian bawah). Rasio lingkar pinggang-panggul dihitung dengan membagi ukuran lingkar pinggang dengan lingkar panggul (7). Beberapa penelitian menunjukkan bahwa pengukuran lingkar pinggang memiliki korelasi yang lebih baik dengan distribusi lemak pada abdomen dibandingkan dengan IMT. Saat hanya dilakukan pengukuran lingkar pinggang saja, WHO merekomendasikan cut-off point untuk Asia yaitu $\geq 90 \mathrm{~cm}$ untuk laki-laki dan $\geq 80 \mathrm{~cm}$ untuk perempuan. Sedangkan cut-off point untuk RLPP yaitu $\geq 1,0$ untuk laki-laki dan $\geq 0,85$ untuk perempuan (5). Apabila hasil pengukuran melebihi cut-off point maka tergolong berisiko.

Pengukuran kadar glukosa darah seseorang bisa menggunakan berbagai cara diantaranya dengan glukosa darah sewaktu, glukosa darah puasa, dan tes toleransi glukosa oral (TTGO), yaitu dengan memberikan 75 gram glukosa yang dilarutkan dalam air $250 \mathrm{~mL}$ dan diminum dalam waktu 5 menit (8). TTGO memiliki kelebihan yaitu dapat menyimpulkan suatu data mengenai resiko seseorang memiliki diabetes atau sudah memiliki diabetes melitus. Apabila kadar glukosa darah melebihi normal tetapi tidak cukup tinggi untuk disebut diabetes maka keadaan ini disebut dengan pre-diabetes. Pre-diabetes merupakan sebuah kondisi yang bisa menjadi penyakit diabetes melitus tipe 2. Diabetes miitus bisa menjadi awal berbagai masalah kesehatan sehingga lebih baik melakukan pencegahan (9). Tujuan penelitian ini adalah untuk menganalisis hubungan pengukuran LP dan RLPP dengan kadar glukosa plasma menggunakan metode TTGO pada orang dewasa

\section{BAHAN DAN METODE}

Penelitian ini merupakan penelitian observasional analitik dengan pendekatan cross sectional yang dilaksanakan pada bulan November-Desember 2014. Populasi dalam penelitian adalah semua orang yang berada di Kelurahan Klojen Kota Malang. Pengambilan sampel dilakukan dengan pemilihan melalui kriteria inklusi dan eksklusi. Kriteria inklusi yaitu responden memiliki usia $>18$ tahun sampai 40 tahun dan bersedia menjadi responden. Sementara kriteria eksklusi adalah 
responden yang memiliki penyakit diabetes melitus dan responden merupakan ibu hamil. Berdasarkan jumlah sampel yang dihitung didapatkan jumlah sampel minimal yaitu 75 orang. Hal yang dapat dilakukan untuk menghindari terjadinya kesalahan dalam penelitian yaitu dengan menambahkan $10 \%$ dari jumlah sampel sehingga jumlah sampel menjadi 83 orang sehingga apabila mendapatkan responden yang ternyata kurang sesuai dengan kriteria yang diinginkan memiliki cadangan untuk mengganti data dengan responden lain yang sesuai dengan kriteria.

Teknik pengambilan sampel yang digunakan dalam penelitian ini adalah multistage random sampling. Lokasi penelitian yang digunakan berada di Kelurahan Klojen Kota Malang yang memiliki 7 RW (Rukun Warga) dengan 53 RT (Rukun Tetangga), dari 7 RW tersebut dipilih 3 RW secara acak. Kemudian dari 3 RW dipilih beberapa RT secara acak dan didapatkan 4 RT yaitu RT 1, RT 3, RT 6, dan RT 9. Pemilihan sampel pada tingkat Kepala Keluarga menggunakan simple random sampling, yaitu dari semua nama kepala keluarga dari RT yang terpilih dijadikan satu kemudian dipilih 75 orang secara acak.

Data glukosa plasma diperoleh melalui pengukuran glukosa darah puasa dengan cara responden melaksanakan puasa paling sedikit 8 jam (mulai malam hari) sebelum pemeriksaan, minum air puth tanpa gula tetap diperbolehkan. Kemudian diberikan 75 gram gula pasir yang dilarutkan ke dalam $250 \mathrm{~mL}$ air, setelah 2 jam maka kadar glukosa darah diukur kembali. Selama proses pemeriksaan, subjek yang diperiksa tetap istirahat dan tidak merokok Glukosa darah diukur dengan menggunakan glucko-stick yaitu responden diambil darahnya kemudian dibaca menggunakan glucosemeter. Hasil dari pengukuran glukosa darah dinyatakan dalam $\mathrm{mg} / \mathrm{dL}$.

Lingkar pinggang adalah besaran yang diukur dengan menggunakan metline dan dinyatakan dalam $\mathrm{cm}$. Pengukuran dilakukan di daerah antara crista iliaca dan costa XII yang memiliki keliling dinding perut terkecil. Lingkar pinggang diukur dalam posisi berdiri tegak dan tenang. Baju penghalang pengukuran disingkirkan. Kemudian, pita pengukur dilingkarkan ke daerah antara lower margin dan crista iliaca. Pita pengukur tidak boleh menekan kulit terlalu ketat dan sejajar dengan lantai. Pengukuran dilakukan saat akhir ekspirasi normal. Lingkar pinggang dinyatakan dalam $\mathrm{cm}$ dengan cut off point untuk laki-laki $\geq 90 \mathrm{~cm}$ dan perempuan $\geq 80 \mathrm{~cm} \mathrm{(4).}$

Rasio lingkar pinggang-panggul merupakan nilai yang didapat dengan membagi nilai lingkar pinggang terhadap lingkar panggul. Rasio lingkar pinggangpanggul didapatkan dengan membagikan nilai lingkar pinggang terhadap nilai lingkar panggul. Pada pengukuran lingkar panggul pita pengukur dililitkan pada bagian atas symphisis asis pubis dan bagian maksimum dari rego gluteus. Cut off point RLPP untuk laki-laki $\geq 1,0$ dan $\geq$ 0,85 untuk perempuan (4). Saat dilakukan pengukuran, responden berganti pakaian menggunakan pakaian yang disediakan oleh peneliti, kemudian dilakukan pengukuran di ruang tertutup.

Analisis univariat merupakan analisis yang dilakukan terhadap tiap variabel dalam hasil penelitian. Hasil analisis univariat akan disajikan dalam bentuk tabel dan narasi. Analisis bivariat dilakukan menggunakan SPSS, normalitas data diketahui dengan menggunakan Uji Kolmogorov Smirnov. Hubungan antara variabel bebas dan variabel terikat menggunakan Uji koefisien kontingensi dan uji korelasi Spearman. Interval kepercayaan yang digunakan adalah $95 \%$. Hipotesis nol ditolak, artinya ada hubungan. Bila $\alpha<\rho$ value $(0,05)$ dan hipotesis nol diterima bila $\alpha>\rho$ value, artinya tidak ada hubungan.

\section{HASIL}

\section{Karakteristik responden}

Sebagian besar responden berjenis kelamin perempuan (68\%) dan berusia 30-39 tahun (53\%). Lingkar pinggang yang melebihi $80 \mathrm{~cm}$ bagi perempuan dan lebih dari $90 \mathrm{~cm}$ untuk laki-laki dinyatakan berisiko memiliki diabetes. Rerata LP hampir sama baik antara yang berisiko maupun yang tidak berisiko. Rerata LP sebesar $80,29 \mathrm{~cm}$ $(\mathrm{SD} \pm 10,57)$ untuk perempuan dan $81,04 \mathrm{~cm}(\mathrm{SD} \pm 12,79)$ untuk laki-laki. Demikian juga sebagian besar responden tidak berisiko mengalami DM berdasarkan rerata RLPP yaitu pada perempuan sebesar $0,82(\mathrm{SD} \pm 0,058)$ dan 0,86 $(\mathrm{SD} \pm 0,067)$ untuk laki-laki (Tabel 1).

\section{Kadar glukosa plasma}

Sebagian besar responden (99\%) tidak berisiko mengalami penyakit DM berdasarkan rerata kadar 
Tabel 1. Distribusi responden berdasarkan LP dan RLPP

\begin{tabular}{|c|c|c|c|c|c|c|}
\hline \multirow{3}{*}{ Variabel } & \multicolumn{4}{|c|}{ Kategori } & \multirow{2}{*}{\multicolumn{2}{|c|}{$\begin{array}{c}\text { Total } \\
(n=75)\end{array}$}} \\
\hline & \multicolumn{2}{|c|}{ Tidak berisiko } & \multicolumn{2}{|c|}{ Berisiko } & & \\
\hline & $\mathbf{n}$ & $\%$ & $\mathbf{n}$ & $\%$ & $\mathbf{n}$ & $\%$ \\
\hline \multicolumn{7}{|l|}{$\mathbf{L P}$} \\
\hline Laki-laki & 17 & 23 & 7 & 9 & 24 & 32 \\
\hline Perempuan & 22 & 29 & 29 & 39 & 51 & 68 \\
\hline Total & 39 & 52 & 36 & 48 & 75 & 100 \\
\hline \multicolumn{7}{|l|}{ RLPP } \\
\hline Laki-laki & 23 & 31 & 1 & 1 & 24 & 32 \\
\hline Perempuan & 34 & 45 & 17 & 23 & 51 & 68 \\
\hline Total & 57 & 76 & 18 & 24 & 75 & 100 \\
\hline
\end{tabular}

LP = lingkar pinggang; RLPP = rasio lingkar pinggang-panggul

glukosa plasma puasa yaitu sebesar $92,3 \mathrm{~g} / \mathrm{dl}(\mathrm{SD} \pm$ 0,115). Demikian juga dengan kadar glukosa plasma TTGO yang sebagian besar $(96 \%)$ termasuk kategori normal dan hanya ada 3 responden (4\%) yang mengalami toleransi glukosa terganggu dengan kadar glukosa plasma lebih dari 140 g/dl. Rerata kadar glukosa plasma TTGO responden sebesar 106,53 $\mathrm{g} / \mathrm{dl}(\mathrm{SD} \pm 0,197)$.

\section{Hubungan usia dengan kadar glukosa plasma TTGO}

Berdasarkan hasil uji normalitas menggunakan Kolmogorov Smiirnov, usia terdistribusi tidak normal dan glukosa plasma TTGO terdistribusi normal. Hasil uji statistik antara variabel usia dengan kadar glukosa plasma TTGO menggunakan uji contingency coefficient diperoleh nilai $\mathrm{p}$ (p value) 0,081 dan menggunakan uji Spearman Correlation diperoleh nilai korelasi $(\mathrm{r}=0,160)$ dan $\mathrm{p}$ ( $\mathrm{p}$ value $) 0,169$. Adapun kesimpulan dari hasil tersebut yaitu tidak ada hubungan yang signifikan antara usia dengan kadar glukosa plasma TTGO (p>0,05) (Gambar 1).

\section{Hubungan lingkar pinggang dengan kadar glukosa plasma TTGO}

Berdasarkan hasil uji normalitas menggunakan Kolmogorov Smiirnov, LP terdistribusi tidak normal dan glukosa plasma TTGO terdistribusi normal. Hasil uji statistik antara variabel LP dengan kadar glukosa plasma TTGO menggunakan uji contingency coefficient diperoleh nilai $\mathrm{p}$ ( $p$ value) 0,066 dan menggunakan uji Spearman Correlation diperoleh nilai korelasi $(\mathrm{r}=0,091)$ dan $\mathrm{p}$ (pvalue) 0,435. Artinya, tidak ada hubungan yang

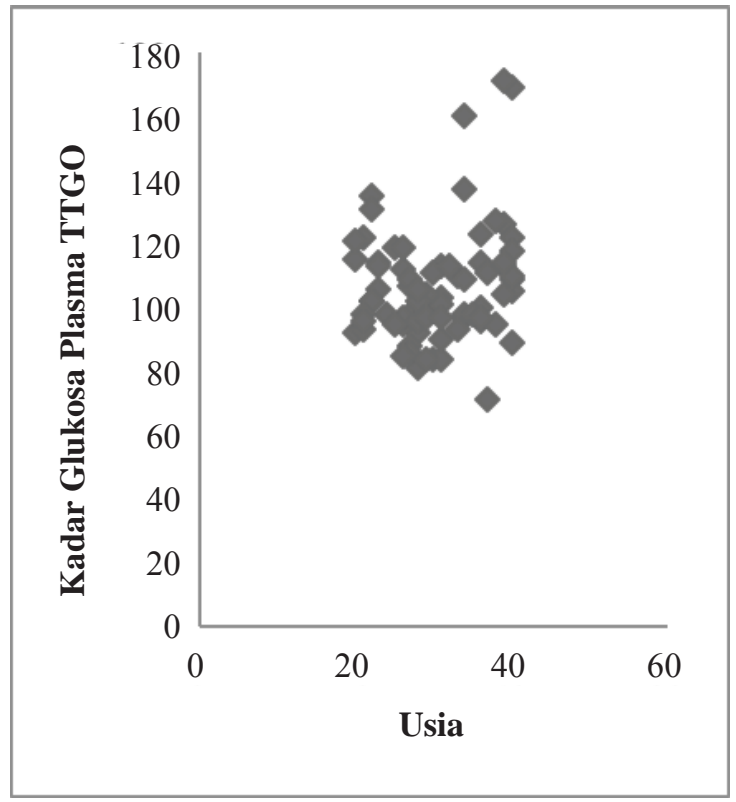

Gambar 1. Hubungan usia dengan kadar glukosa plasma TTGO

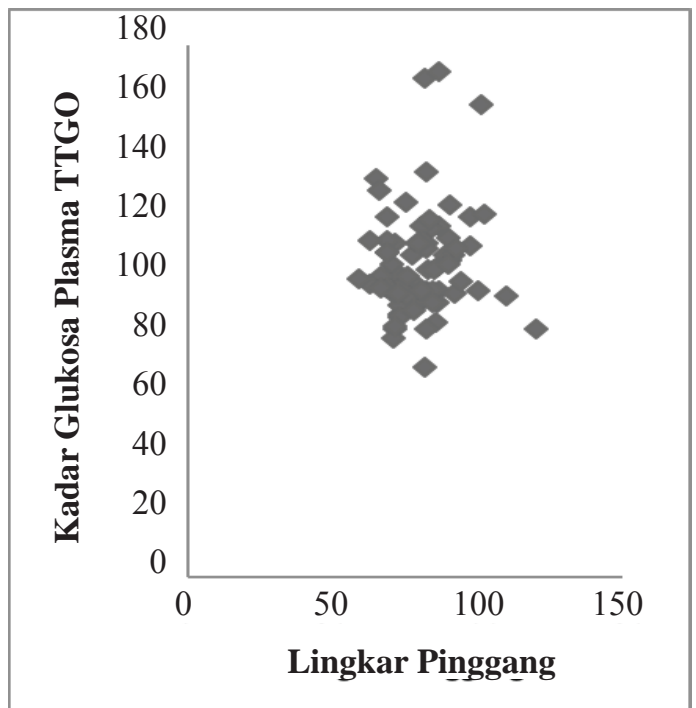

Gambar 2. Hubungan lingkar pinggang dengan kadar glukosa plasma TTGO

signifikan antara LP dengan kadar glukosa plasma TTGO ( $>>0,05)$ (Gambar 2).

\section{Hubungan rasio lingkar pinggang-panggul dengan kadar glukosa plasma TTGO}

Berdasarkan hasil uji normalitas menggunakan Kolmogorov Smiirnov, RLPP terdistribusi tidak normal 


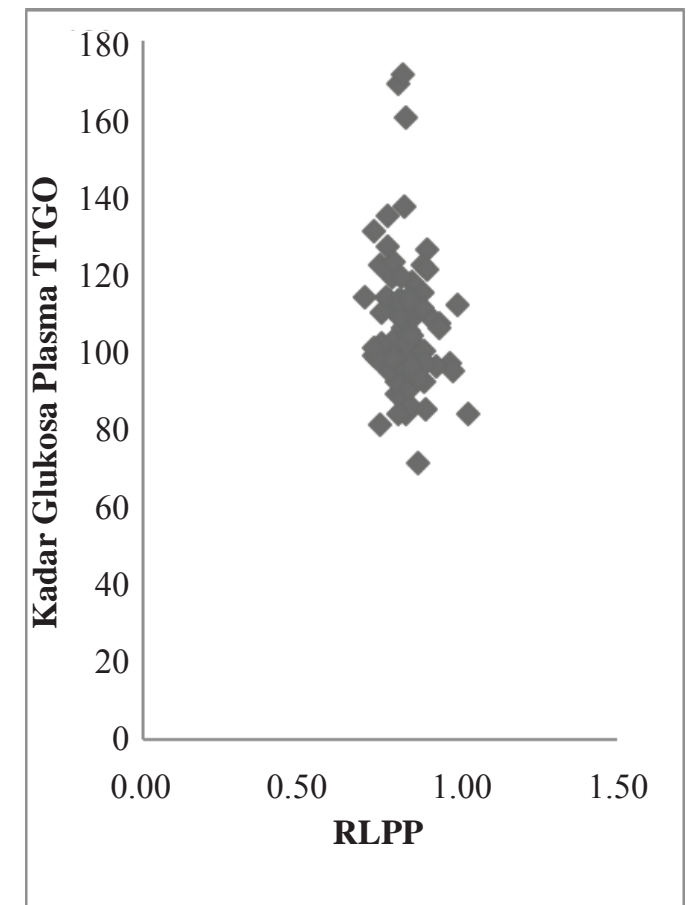

Gambar 3. Hubungan Rasio Lingkar Pinggang-Panggul dengan Kadar Glukosa Plasma TTGO

dan glukosa plasma TTGO terdistribusi normal. Dari hasil uji statistik antara variabel LP dengan kadar glukosa plasma TTGO menggunakan uji contingency coefficient diperoleh nilai $\mathrm{p}$ ( $p$ value) 0,321 dan menggunakan uji Spearman Correlation diperoleh nilai korelasi $(\mathrm{r}=-0,190)$ dan $\mathrm{p}$ (pvalue) 0,102 . Kesimpulannya adalah tidak ada hubungan yang signifikan antara RLPP dengan kadar glukosa plasma TTGO (p>0,05) (Gambar 3).

\section{BAHASAN}

\section{Karakteristik responden}

Usia responden dalam penelitian ini berkisar antara 20 - 40 tahun, yaitu dengan kategori usia $20-29$ tahun sebanyak $46,67 \%$ dan usia $30-40$ tahun sebanyak 53,3\%. Rerata usia pada penelitian ini yaitu 30,5 tahun. Seseorang dapat dikatakan produktif apabila telah memasuki fase usia dewasa dini yaitu $18-40$ tahun, dalam fase ini juga seseorang telah mendapat pengaruh dari luar yang dapat mengakibatkan peningkatan dan penurunan kondisi fisik dan klinis (10).

Kejadian sindroma metabolik dapat dipengaruhi oleh usia. Prevalensi sindroma metabolik akan semakin meningkat bila usia semakin bertambah (11). Dari hasil penelitian Shuldiner tahun 2001 menyatakan bahwa orang yang berusia di atas 40 tahun kemungkinan memiliki risiko yang lebih tinggi untuk menderita penyakit-penyakit degeneratif, seperti DM tipe 2 . Risiko perkembangan DM tipe 2 kemungkinan berkaitan dengan asupan makanan tinggi energi, kurangnya aktivitas fisik dan latihan jasmani dalam jangka waktu lama. Jumlah lemak tubuh akan meningkat sesuai dengan peningkatan umur. Menurut penelitian Garrows mengenai pengaruh obesitas pada gizi manusia dan dietetik menyatakan bahwa prevalensi obesitas akan meningkat terus sampai umur 50 tahun untuk pria, dan umur 65 tahun untuk wanita (12). Sehingga dapat disimpulkan bahwa usia dapat berpengaruh terhadap kejadian DM, akan tetapi juga tergantung dengan faktor lain seperti asupan dan aktifitas fisik.

Obesitas sentral maupun perifer dapat meningkatkan resiko berbagai macam penyakit yang mematikan. Lingkar pinggang dapat mengukur jaringan lemak subkutan dan intra-abdominal. LP mudah interpretasinya dan memiliki korelasi yang lebih baik dengan massa lemak visceral. Jaringan lemak visceral erat korelasinyan dengan sejumlah komplikasi metabolik seperti sindrom resistensi insulin, termasuk hiperinsulinemia, hiperkolesterolemia, hiperglikemia, hipertrigliseridemia, dan tingginya kadar low density lipoprotein (LDL). Dibandingan dengan rasio lingkar pinggang-panggul, LP lebih kuat korelasinya dengan total jaringan lemak tubuh yang dinilai dengan BMI (13).

\section{Lingkar pinggang dan rasio lingkar pinggang-panggul responden}

Berdasarkan hasil penelitian menurut data lingkar pinggang, proporsi lingkar pinggang hampir sama $(<80$ $\mathrm{cm}$ untuk perempuan dan $<90 \mathrm{~cm}$ untuk laki-laki) yaitu sebesar $50,66 \%$ dan $49,33 \%$ berisiko ( $\geq 80 \mathrm{~cm}$ untuk perempuan dan $\geq 90 \mathrm{~cm}$ untuk laki-laki). Rasio lingkar pinggang-panggul, sebagian besar responden tidak berisiko $(<0,85$ untuk perempuan dan $<0,1$ untuk lakilaki) yaitu sebesar $73,33 \%$ dan $26,67 \%$ berisiko $(\geq 0,85$ untuk perempuan dan $\geq 0,1$ untuk laki-laki).

Lingkar Pinggang dan Rasio Lingkar Pinggang Panggul merupakan salah satu metode pengukuran 
yang dapat digunakan untuk memprediksi jumlah lemak abdominal/sentral. Cut off point yang sering dipergunakan untuk menentukan adanya obesitas abdominal pada berbagai studi adalah nilai Lingkar Pinggang pada lakilaki yang lebih dari $90 \mathrm{~cm}$ dan lebih dari $80 \mathrm{~cm}$ pada perempuan serta nilai RLPP lebih dari 1,0 pada laki-laki dan lebih dari 0,85 pada perempuan (14).

Banyaknya jumlah responden yang berisiko berdasarkan lingkar pinggang dan jauh lebih besarnya simpangan deviasi nilai rata-rata LP dibandingkan dengan RLPP, kemungkinan disebabkan nilai LP diukur secara tunggal tanpa pembanding, sedangkan RLPP menggunakan pembanding. Oleh sebab itu, untuk menilai obesitas sentral sebaiknya menggunakan RLPP, kecuali jika LP sudah dikategorikan dengan lebih spesifik, tidak hanya menggunakan cut-off point yang hanya bisa dinyatakan sebagai berisiko atau tidak berisiko (15). Menurut Halim S, pengukuran lemak intra-abdomen lebih berkorelasi saat menggunakan pengukuran LP dibandingkan dengan RLPP dan IMT (16). Penilaian obesitas intra-abdomen sebaiknya menggunakan RLPP dikarenakan adanya pembanding.

\section{Kadar glukosa plasma responden}

Berdasarkan hasil penelitian menurut kadar glukosa plasma puasa, sebagian besar responden tidak berisiko $(<126 \mathrm{gr} / \mathrm{dl})$ yaitu sebesar $98,7 \%$ dan $1,3 \%$ berisiko ( $\geq 126 \mathrm{gr} / \mathrm{dl})$ mengalami diabetes melitus. Begitu pula dengan kadar glukosa plasma TTGO, sebagian besar responden memiliki glukosa plasma normal $(<140 \mathrm{gr} /$ dl) yaitu sebesar $96,0 \%$ dan $4,0 \%$ mengalami toleransi glukosa terganggu ( $\geq 140 \mathrm{gr} / \mathrm{dl}$ - $199 \mathrm{gr} / \mathrm{dl})$. Responden yang mengalami TGT berada pada 1 kelompok usia yaitu usia 30-40 tahun.

Kadar glukosa plasma puasa merupakan salah satu metode penegakan diagnosis Diabetes Mellitus Tipe 2. Kadar glukosa plasma puasa lebih sentistif untuk memprediksi risiko timbulnya Diabetes Mellitus Tipe 2 pada pre diabetes dalam jangka waktu $5-6$ tahun mendatang, terutama golongan umur $\leq 55$ tahun (17). Kadar glukosa plasma puasa dipengaruhi oleh banyak faktor, antara lain konsumsi makanan dan latihan jasmani. Kombinasi pola makan tinggi lemak, karbohidrat sederhana dan makanan olahan dengan kurang aktivitas fisik dan olah raga berkaitan dengan peningkatan kadar glukosa plasma puasa (18). Pengaturan pola hidup dengan diit dan latihan jasmani dapat menghambat resistensi insulin dan memperbaiki komponen - komponen sindroma metabolik. Dapat disimpulkan bahwa untuk dapat mengetahui risiko DM dapat diukur menggunakan kadar glukosa plasma puasa maupun TTGO, akan tetapi tetap dipengaruhi oleh faktor lain seperti asupan dan aktifitas fisik.

\section{Hubungan lingkar pinggang dengan kadar glukosa plasma responden}

Berdasarkan hasil analisis data LP dan RLPP dan kadar glukosa plasma menggunakan TTGO didapatkan tidak adanya hubungan antara LP dan RLPP dengan kadar glukosa plasma menggunakan TTGO. Hasil penelitian ini sejalan dengan hasil penelitian Lipoeto pada tahun 2007 yang menyatakan tidak ada korelasi antara nilai antropometri dengan kadar glukosa plasma. Menurut penelitian Sabena menyatakan tidak ada hubungan antara RLPP dengan kadar glukosa plasma pada penderita baru diabetes melitus tipe 2 (19). Hasil ini berbeda dengan penelitian Jalal dkk yang menyatakan adanya korelasi positif antara lingkar pinggang dengan kadar trigliserida, kadar glukosa plasma dan tekanan darah (20). Hasil penelitian yang menunjukkan tidak adanya hubungan bisa disebabkan oleh asupan makanan dan aktifitas setiap orang yang berbeda.

Hasil penelitian menunjukkan jumlah dan distribusi lemak tubuh terutama pada bagian perut tidak dapat menggambarkan proses penyerapan karbohidrat dalam tubuh. Padahal secara teoritis, resistensi insulin terjadi dikarenakan salah satunya oleh peningkatan jumlah lemak tubuh yang dapat menyebabkan meningkatnya kadar glukosa plasma, hal ini dapat dijelaskan dengan patofisiologi terjadinya DM. Pada fase awal saat resistensi insulin telah terjadi maka sekresi insulin akan meningkat dan kadar glukosa plasma masih dapat dipertahankan dalam kadar normal. Pada fase lanjut saat kinerja sel-sel pancreas mulai berkurang maka sekresi insulin akan menurun secara bertahap sehingga timbul hiperglikemia puasa ringan sampai berat (21). Diabetes sering tidak terdiagnosa setelah bertahun-tahun dikarenakan perkembangan hiperglikemia yang secara 
bertahap dan pada tahap awal, sering tidak cukup untuk menggambarkan salah satu dari gejala klasik diabetes (10).

Beberapa faktor risiko yang berpengaruh besar terhadap kejadian diabetes melitus tipe 2 diantaranya yaitu memiliki umur $\geq 45$ tahun, adanya riwayat keluarga $\mathrm{DM}$, ras, memilki riwayat toleransi gula darah terganggu, memiliki riwayat gula darah puasa terganggu, hipertensi, dislipidemia dan memiliki riwayat diabetes gestasional atau melahirkan bayi dengan berat badan lahir lebih dari $4 \mathrm{~kg}$ (9). Menurut penelitian Nguyen Insiden dari onset diabetes tipe 2 akan meningkat seiring dengan bertambahnya usia (22). Hasil penelitian Theresia menyatakan bahwa tidak terdapat hubungan antara overweight dengan peningkatan gula darah (23).

Berbagai studi menunjukkan bahwa batas kadar glukosa plasma puasa dan kadar glukosa plasma menggunakan TTGO sesungguhnya lebih rendah dari batas kadar glukosa plasma yang saat ini digunakan, mengingat bahwa saat glukosa plasma masih dibawah batas "normal" mungkin sudah terjadi peningkatan risiko komplikasi diabetes mikrovaskuler dan makrovaskuler (24).

Konsumsi makanan padat energi (tinggi lemak dan gula) dan rendah serat berhubungan dengan kadar glukosa plasma. Makanan tinggi energi berhubungan dengan obesitas, resistensi insulin sehingga dapat memacu peningkatan kadar glukosa plasma (17). Latihan jasmani meningkatkan sensitivitas insulin sehingga membantu penurunan kadar glukosa plasma. Latihan jasmani secara teratur 3 sampai 5 kali per minggu dengan durasi lebih dari 30 menit dianjurkan pada Diabetes Mellitus Tipe 2. Hasil penelitian Suminarti, pelaksanaan senam dapat menurunkan berat badan dan kadar glukosa plasma puasa dan 2 jam postprandial. Rata - rata penurunan kadar glukosa plasma puasa $1,06 \pm 47,74$ dan sebesar 41,94 $\pm 75,17$ pada kadar glukosa plasma 2 jam postprandial (25). Dalam penelitian ini penulis tidak melakukan pemeriksaan konsumsi makanan dikarenakan adanya keterbatasan waktu untuk menyelesaikan penelitian.

Pengukuran lingkar pinggang dan lingkar panggul merupakan suatu pengukuran paling sederhana dan mudah yang bisa dilakukan untuk menilai resiko penyakit degeneratif, tetapi ternyata dengan mengukur LP dan RLPP saja tidak cukup untuk menggambarkan resiko penyakit diabetes melitus dan kadar glukosa plasma. Pengukuran IMT juga bisa digunakan untuk menilai resiko penyakit degeneratif. Apabila memnugkinkan, lebih baik menggunakan kedua pengukuran tersebut (2).

Dari penjelasan diatas dapat disimpulkan bahwa tidak ada hubungan antara LP dan RLPP terhadap kadar glukosa plasma TTGO yang dapat dipengaruhi oleh berbagai faktor diantaranya usia, asupan energi dan aktifitas fisik responden. Keterbatasan dalam penelitian ini adalah peneliti tidak mengambil data mengenai asupan energi dan aktifitas fisik responden yang dapat mempengaruhi kadar glukosa plasma responden. Pada saat penelitian, peneliti hanya menggunakan glucose meter yang memiliki akurasi lebih rendah dibandingkan dengan uji laboratorium serta saat penelitian peneliti menggunakan larutan gula pasir bukan menggunakan glukosa murni yang dilarutkan dalam $250 \mathrm{~mL}$ air.

\section{SIMPULAN DAN SARAN}

Rerata LP responden hampir sama dan sebagian besar RLPP responden normal. Kadar glukosa plasma puasa dan glukosa plasma TTGO responden sebagian besar normal. Tidak ada korelasi antara LP dan kadar glukosa plasma menggunakan TTGO. Demikian juga tidak ada korelasi antara RLPP dan kadar glukosa plasma menggunakan TTGO. Penelitian selanjutnya dapat mengkaji hubungan asupan energi, aktivitas fisik dengan kadar glukosa plasma menggunakan TTGO. Sebaiknya dilakukan pengukuran plasma vena dengan analisis enzimatik di laboratorium sehingga hasil kadar glukosa plasma yang dihasilkan lebih akurat dan menggunakan larutan glukosa standar.

\section{RUJUKAN}

1. CDC. Athropometry Procedures Manual. National Health and Nutrition Examination Survey (NHANES) 2007. [serial online] 2007 [cited Sep 2014]. Available online: URL: https://www.cdc.gov/nchs/data/nhanes/ nhanes_07_08/manual_an.pdf

2. WHO. Waist circumference and waist-hip ratio report of a who expert consultation. Geneva: WHO; 2008.

3. National Institute of Diabetes and Digestive and Kidney Disease. Insulin resistance and prediabetes. USA: National Institute of Health; 2008. 
4. Gibson R. Principles of nutritional assessment $2^{\text {nd }}$ Ed. New York: Oxford University Press; 2005.

5. Siswanto IH. Prevalensi Diabetes mellitus tipe 2 pada obesitas sentral di Kelurahan Tajur Ciledug tahun 200 [Karya Tulis Ilmiah]. Jakarta: Fakultas Kedokteran Universitas Islam Negeri Syarif Hidayatullah; 2009.

6. Dagan SS, Segev S, Novikov I, Dankner R. Waist circumference vs body mass index in association with cardiorespiratory fitness in healthy men and women: a cross sectional analysis of 403 subjects. Nutr J 2013;12:12.

7. Fahmida, Dillon. Handbook nutritional assessment. Jakarta: SEAMEO-TROPMED RCCN UI; 2007.

8. Perkeni. Konsensus pengelolaan diabetes melitus. Jakarta: EGC; 2011.

9. American Diabetes Association. Standards of medical care in diabetes-2014. Diabetes Care 2014;37(Supp 1):S14-80.

10. Widyana LE. Hubungan antara estimasi lemak dan kolesterol dengan tekanan darah di Kecamatan Kedungkandang Kota Malang [Karya Tulis Ilmiah]. Malang: Universitas Brawijaya; 2013.

11. Grundy SM, Brewer Jr B, Cleeman JI, Smith Jr SC, Lenfant $\mathrm{C}$, and for the Conference Participants. Definition of metabolic syndrome: report of the national heart, lung, and blood institute/american heart association conference on scientific issues related to definition. Circulation 2004;109:433-8.

12. Garrows. Obesity in human nutrition and dietetics. London: Chuechill, Livingstone; 2000.

13. Okosun IS, Prewitt TE, Cooper RS. Abdominal obesity in the United States : prevalence and attributable risk of hypertension. J Hum Hypertens 1999;13(7):425-30.

14. Sandi W. Hubungan lingkar pinggang dan rasio lingkar pinggang panggul dengan kadar gula darah puasa pada laki-laki dewasa [Karya Tulis Ilmiah]. Surakarta: Fakultas Kedokteran Universitas Sebelas Maret; 2010.

15. Lipoeto NI, Eti Y, Zulkarnain E, Intan W. Hubungan antropometri dengan kadar glukosa darah. Medika 2007;23-8.
16. Halim S. The tale of obesity :challenges and solution. Med J Indonesia 2003;12(1):53-62.

17. Fitri RI, Yekti W. Asupan energi, karbohidrat, serat, beban glikemik, latihan jasmani dan kadar gula darah pada pasien diabetes mellitus tipe 2. M Med Indones 2012;46(2):12131 .

18. Dam V, Rimm EB, Willett WC, Stampfer MJ, Hu FB. Dietary patterns and risk type 2 diabetes mellitus in U.S men. Am J Coll Phys 2002;136(3):201-9.

19. Sabena E. Hubungan indek massa tubuh, rasio lingkar pinggang panggul, konsumsi energi dan karbohidrat dengan kadar glukosa darah pada penderita baru DMTTI rawat jalan (studi di RSU Tidar Magelang) [Karya Tulis Ilmiah]. Semarang: Fakultas Kedokteran Universitas Diponegoro; 2003.

20. Jalal F, Nur IL, Novia S, Fadil O. Hubungan lingkar pinggang dengan kadar kadar glukosa darah, trigliserida dan tekanan darah pada Etnis Minang di Kabupaten Padang Pariaman, Sumatra Barat [Tesis]. Padang: Universitas Andalas; 2005.

21. Sanusi H. Patogenesis hiperglikemia diabetes melitus tipe 2. J Med Nus 2001;22:431-7.

22. Nguyen QM, Xu JH, Chen W, Srinivasan SR, Berenson GS. Correlates of age onset of type 2 diabetes among relatively young black and white adults in a community. Diabetes Care 2012;35(6):1341-6.

23. Theresia TL. Hubungan overweight dengan peningkatan kadar gula darah pada pedagang pusat pasar Medan [Karya Tulis Ilmiah]. Medan: Fakultas Kedokteran Universitas Sumatera Utara; 2012.

24. Setiawan M. Pre-diabetes dan peran $\mathrm{HbA1c}$ dalam skrining dan diagnosis awal diabetes melitus. Fakultas Kedokteran Universitas Muhammadiyah Malang; 2011.

25. Suminarti W, Purba M, Handayani ND, Wiyono P. Perubahan berat badan dan kadar glukosa darah pada kelompok senam diabetes PERSADIA cabang RS DR Sardjito Yogyakarta. Yogyakarta: KONAS PERSAGI; 2002. 